\title{
Detection of Brucella Genome by Real Time PCR from the Milk of Small Ruminants in the West Bank, Palestine
}

\author{
Elena AWWAD ${ }^{1,2)}$, Mohammad FARRAJ ${ }^{3)}$, Tamer ESSAWI ${ }^{3)}$, Israr SABRI ${ }^{3)}$, Kamel ADWAN ${ }^{4)}$, Issa RUMI $^{22}$, \\ Assad MANASRA ${ }^{2}$, Stelian BĂRĂITĂREANU ${ }^{1)}$, Maria Rodica GURĂU ${ }^{1}$, Doina DANEŞ ${ }^{1)}$ \\ 1) University of Agronomic Science and Veterinary Medicine, Facultaty of Veterinary Medicine, Bucharest, \\ Romania. \\ ${ }^{2)}$ Ministry of Agriculture, General Directorate of Veterinary Services and Animal Health, Central \\ Veterinary Laboratory, Ramallah, Palestine \\ ${ }^{3)}$ Master Program in Clinical Laboratory Science (MCLS), Birzeit University, Birzeit, Palestine \\ ${ }^{4)}$ Department of Biology and Biotechnology, An-Najah National University, Nablus, Palestine \\ * Corresponding author: danes.doina@gmail.com
}

Bulletin UASVM Veterinary Medicine 73(1) / 2016,

Print ISSN 1843-5270; Electronic ISSN 1843-5378

DOI:10.15835/buasvmcn-vm: 11677

\begin{abstract}
Brucellosis is an endemic disease of the small ruminants in Palestine, posing a big threat to humans due to its zoonotic character. The rapid detection is the main goal in case of outbreak in order to implement the specific control policy. In the control of the brucellosis, the fast detection must offset the impairment of the "test and slaughter" policy caused by the financial burden. The aim of this study was to develop accurate and rapid molecular techniques to detect Brucella in sheep and goat milk. Recently, has been reported an outbreak in Qibbiya (small village of Ramallah district) counting 11 adult people and a 10 month old baby: subsequently, for serological testing, were collected serum samples from 350 animals from the 14 suspected flocks. The milk samples from 33 seropositive animals were check using an in-house PCR protocol for the Brucella genome identification. The results revealed the presence of Brucella spp genome in 78.8\% (26/33) of the milk samples, while only $27.2 \%(9 / 33)$ of milk samples were positive at isolation on Brucella agar. All suspected and confirmed animals were quarantined and necessary measures were taken. Two weeks later, all sero-negative and real time PCR negative animals, were retested using Rose Bengal test and were negatives. Identification of Brucella spp by classical methods delay the implementation of control measures. The development of such a rapid and sensitive assay as real time PCR give a reliable tool to be use by authorities, in order to control the spread of Brucellosis.
\end{abstract}

Keywords: brucellosis, milk samples, real-time PCR, zoonosis

\section{INTRODUCTION}

Brucellosis is zoonotic disease and important public health problem worldwide, especially in Mediterranean countries (Doganay and Aygen, 2003; Gul and Khan, 2007). The causative agent of Brucellosis is a intracellular gram-negative bacteria belonging to genus Brucella: at this time in this genus are 11 species. The most important pathogen species from this genera is Brucella melitensis, due to his great prevalence in sheeps and goats breeded in Mediteranean area and to zoonotic risk. (Scholz and Vergnaud, 2013; MayerScholl et al., 2010). Infections by Brucellosis are caused significant economic losses which include decrease productivity as a result of abortion, weak offspring, reduced milk production and losses of trade opportunities (FAO, 2010). The B.melitensis infections in small ruminants are still widespread 
in West Bank area, causing human illness, primarily by consumption of contaminated dairy products or as professional diseases. (Saleem et al., 2010; Kaoud et al., 2010; Doganay and Aygen, 2003; Zvizdic et al., 2006; Sanco, 2001). In human, if the disease is not diagnosed and treated promptly and effectively, it can become chronic and affect multiple body systems (FAO, 2010, Saleem et al., 2010; Sanco, 2001; Zvizdic et al., 2006; WHO, 1999).

Several Brucellosis eradication programs have been launched in many countries, but the success of these programs still has not reached the desired level. These programs are based on the vaccination of the animals, carrying out of studies to identify the infected farm animals, the slaughter of animals and limitation of movement from contaminated areas to free regions. (FAO, 2010).

Early detection by valid diagnostic tools is crucial for the control and eradication of Brucellosis (Al-Garadi et al., 2011; Bricker, 2002; Surucuoglu et al., 2009). Culture methods are not always successful as they are time-consuming and the handling of microorganism is hazardous. The sensitivity of the bacteriological culture methods depends on the viability and numbers of Brucella in the sample, and of the nature of the sample which is commonly contaminated with other bacteria (Refai, 2002). Milk is the foremost source of Brucella infection in humans and its testing by bacteriological culture has low sensitivity (Ning et al., 2013; O'Leary et al., 2006).

Serologic methods are rapid, but not conclusive, because not all infected animals produce detectable levels of antibodies and crossreactivity with other antigens can give falsepositive results (Gwida et al., 2011).

Molecular diagnostic techniques represent an important breakthrough in the diagnostic practice. Most of the authors confirmed that realtime PCR is a very sensitive method for detection of Brucella from various samples (Doosti and Ghasemi-Dencodri, 2011; Safarpoor-Denkordi, 2014; Newby et al., 2003; Al-Garadi et al., 2011; Foster et al., 2008; Navarro-Martinez et al., 2008). PCR also has the added advantage of being able to simultaneously detect all species of Brucella genome and differentiate them with high sensitivity and specificity (Sohrabi et al., 2011; Garcia-Yoldi et al., 2006; López Goñi et al., 2009; Mirnejad et al., 2012; Bounaadja et al., 2009).
The main purpose of this study was detection Brucella in milk samples from sero-positive infected animals by using Brucella group RT- $q$ PCR protocol developed in-house. This technique could be really useful for rapid quarantine of infected animals, implementation preventive measures and management of outbreaks. Up to now no article has documented about RT- $q$ PCR investigation of Brucella genome in Palestine. This will enable the veterinary services control and eradicate Brucellosis in Palestine.

\section{MATERIALS AND METHODS}

Samples collection Sheep and goat blood samples were collected from the jugular veins in plain vacutainer tubes without anticoagulant by using aseptic techniques. The samples were kept on ice at about $4{ }^{\circ} \mathrm{C}$ and transported immediately to the laboratory. Tubes were centrifuged at $3000 \mathrm{rpm}$ for $3 \mathrm{~min}$ to separate the serum. The milk samples from sero-positive animals were collected and transported to the laboratory. All milk samples were obtained from animals during their routine milking time, from all 4 quarters of the mammary gland and $200 \mu \mathrm{l}$ sediment of milk was used for detection of Brucella genome by RealTime PCR assay and culture purpose.

The serological Rose-Bengal test. According to OIE and FAO recommendation the Rose-Bengal test was carried out by the addition of $30 \mu \mathrm{l}$ of serum and $30 \mu \mathrm{l}$ of Rose-Bengal reagent (Jovac, Jordan) and was well mixing it was shaken for 4 minutes. Sera were considered positive when showing any degree of agglutination detected as score $(+,++,+++,++++)$ depending on strength of agglutination.

Bacterial isolation from milk samples. The cream and sediment mixtures from each 33 milk samples of sero-positive small ruminants were assessed after centrifugation of milk samples (10 $\mathrm{mL}$ ) at $2000 \mathrm{~g}, 4^{\circ} \mathrm{C}$ for 20 minutes. Cream and sediment were then spread onto Brucella agar plates (Oxoid, UK), incubated at $37^{\circ} \mathrm{C}$ for 2 to 7 days and plates were daily examined for the colony presence and identification according to standard methods.

DNA extraction. Milk samples were centrifuged at $8000 \mathrm{rpm}$ for $15 \mathrm{~min}$ to sediment the bacteria (Romero and Lopez-Goni, 1999). The fatty top layer and supernatant were discarded and $200 \mu \mathrm{l}$ pellet used for the extraction procedure by a commercial 
kit QIAamp RNA Mini Kit (Qiagen, France) according to the manufacturer's instructions. Also was extracted Rev.1 vaccine (Ovejero, Spain) as positive control in this study.

The Real Time PCR Test. In order to perform RT-qPCR in-house protocol to detect of the Brucella spp, DNA of 33 sero-positive milk samples, vaccine strain Rev 1 (Avejero, Spain) as positive control and Brucella negative milk samples were used. Real time PCR was performed with set of primers Brucella group of the region bcsp 31 forward 5'-GCTCGGTTGCCAATATCAATGC-3', reverse 5' GGGTAAAGCGTCGCCAGAAG-3'and probe 5'-6FAM AAATCTTCCACCTTGCCCTTGCCATCA-BHQ1-3' (Probert, 2004). DNA amplification mixture was composed of $7.12 \mu \mathrm{l}$ of nuclease free water, $5 \mu \mathrm{l}$ Qiagen 1 step RT PCR buffer x5 (Qiagen, Cat. No: 210212), $0.8 \mu \mathrm{l}$ dNTPs $(200 \mu \mathrm{M})$ (Qiagen, Ct. No: 210112), $0.5 \mu \mathrm{l}$ forward and reverse primer $(20 \mu \mathrm{M} / \mu \mathrm{l}), 0.5 \mu \mathrm{l}(5 \mu \mathrm{M} / \mu \mathrm{l})$ probe (Syntheza, Israel), $1 \mu \mathrm{l}$ Taq polymerase enzyme (Promega, Cat. No: D1806) and $5 \mu \mathrm{l}$ of DNA product. Amplification was performed by using SmartCycler, France. Reaction was initiated with denaturation at $95^{\circ} \mathrm{C}$ for 3 minutes followed by 50 cycles: $95^{\circ} \mathrm{C}$ for $15 \mathrm{sec}$, annealing and extension at $60^{\circ} \mathrm{C}$ for 35 minutes.

\section{RESULTS AND DISCUSSIONS}

In this study Rose-Bengal test was used to screen serum of 350 suspected animals for Brucella species. Results showed that 9.4\% (33/350) of serum were positive for Brucella. The milk from sero-positive animals was tested by developed RT$q$ PCR protocol in-house and the results showed that $78.8 \%$ (26/33) were positive. Only 9 samples were positive for Brucella when isolation was done (Table 2). By testing milk samples obtained from 33 serologically positive animals, all the $9(27.2 \%)$ positive ruminants detected by bacterial isolation were also detected as positive by the RT-qPCR inhouse assay. Furthermore, 18 (69.2\%) additional milk samples that were negative by bacterial isolation, but positive by RBT gave positive results by RT-qPCR assay. Consequently, the agreement score between the bacterial isolation and the RTqPCR assay was low.

Animals that show negative result do not mean that they are not infected with Brucella spp. Several possible reasons have been taken into account to explain the relatively inconsistent performance of Brucella detection. The Brucella could be located only in the lymph nodes and did not yet reach the milk at the sampling time.

The stage of the infection may influence the antibody level and the number of the bacteria (Alton et al., 1988); the presence of large amounts of host genomic DNA may inhibit the PCR reaction (Navarro et al., 2002); the DNA extraction method used may be crucial for the ability of the PCR assay to detect the bacterium (Romero and Lopez-Goni, 1999). Factors that may compromise DNA recovery from milk include difficulties in disrupting bacterial cell walls, loss of DNA template through extraction procedures, or the presence of potential polymerase inhibitors.

In addition, the amount of milk used for PCR is significant smaller than that required for bacteriological methods, so the number of organisms contained in a sample may thus notreach PCR detection limits (Yousef-Beingi et al., 2005). Therefore, the milk samples were centrifuged and only concentrated bacteria (pellet) was used for extraction.. Two weeks later, all serological and RT-qPCR negative animals, were retested using Rose Bengal test and gave negative result. In case of the high risk of contamination and spread of the agent, the shortest period of time for diagnosis of brucellosis in milk are to take into consideration, so the use of RT-qPCR is advantageous.

Tab. 1. Detection of Brucella spp. in serum and milk samples by RT-qPCR and bacterial isolation recovered from 33 serologically positive animals.

\begin{tabular}{|c|c|c|c|c|c|c|c|c|}
\hline & & \multicolumn{2}{|c|}{ Rose-Bengal test } & \multicolumn{3}{|c|}{ RT-qPCR assay } & \multicolumn{2}{|c|}{ Bacterial isolation } \\
\hline & & positive & negative & & positive & negative & positive & negative \\
\hline $\begin{array}{c}\text { No of } \\
\text { samples }\end{array}$ & Serum & 33 & 317 & Milk & 26 & 7 & 6 & 24 \\
\hline $\begin{array}{c}\% \\
\text { Percentage }\end{array}$ & 350 & $18.2 \%$ & $90.5 \%$ & 33 & $78.8 \%$ & $21.2 \%$ & $18.2 \%$ & $72.7 \%$ \\
\hline
\end{tabular}


This was the first study carried out in practice using the developed in-house protocol of RT-qPCR and it proved to be successfully.

Despite the intensive vaccination program by Brucella melitensis Rev 1 vaccine, the Brucellosis remains in Palestine a significant problem. Identification of Brucella spp by classical methods is time-consuming, delay the implementation of control measures, and it increase the risk of occurrence of more human cases.

Therefore, to dispose of a rapid, accurate and highly sensitive assay as RT-q PCR gives a reliable tool to be used by authorities, in order to implement measures and control of outbreak for the prevention and spread of the disease among human and animal population. In addition to the molecular assays, the serology methods must be performed and, if possible, confirmed by bacteriological isolation, in accordance with the epidemiological purpose.

The implementation of "test-and-slaughter" policy for infected animals is hindered by lack of financial resources to compensate affected owners.
Some farmers agree to slaughter their animals, but, due to the high level of errors in serology methods, the culling of all sero-positive animals in the flock leads to high economic losses. It was pointed by our study: instead of slaughtering 33 sero-positive animals, only 26 were slaughtered according to the result of real-time PCR assay and moreover, the necessary preventive measures were sooner implemented.

To reduce the prevalence of human infections, in the endemic areas it is extremely important to carry out awareness campaigns to emphasize to farmers to use only boiled milk for all purposes, because most cases occur after consumption of unpasteurized dairy product.

In addition, measures should be adopted to deal with animal health in general and with infected animals in particular. Finally, eradication of brucellosis can only be achieved by test-andslaughter policy combined with animal movement control. Implementing these preventive measures and compensating owners may be effective in controlling brucellosis in Palestine.

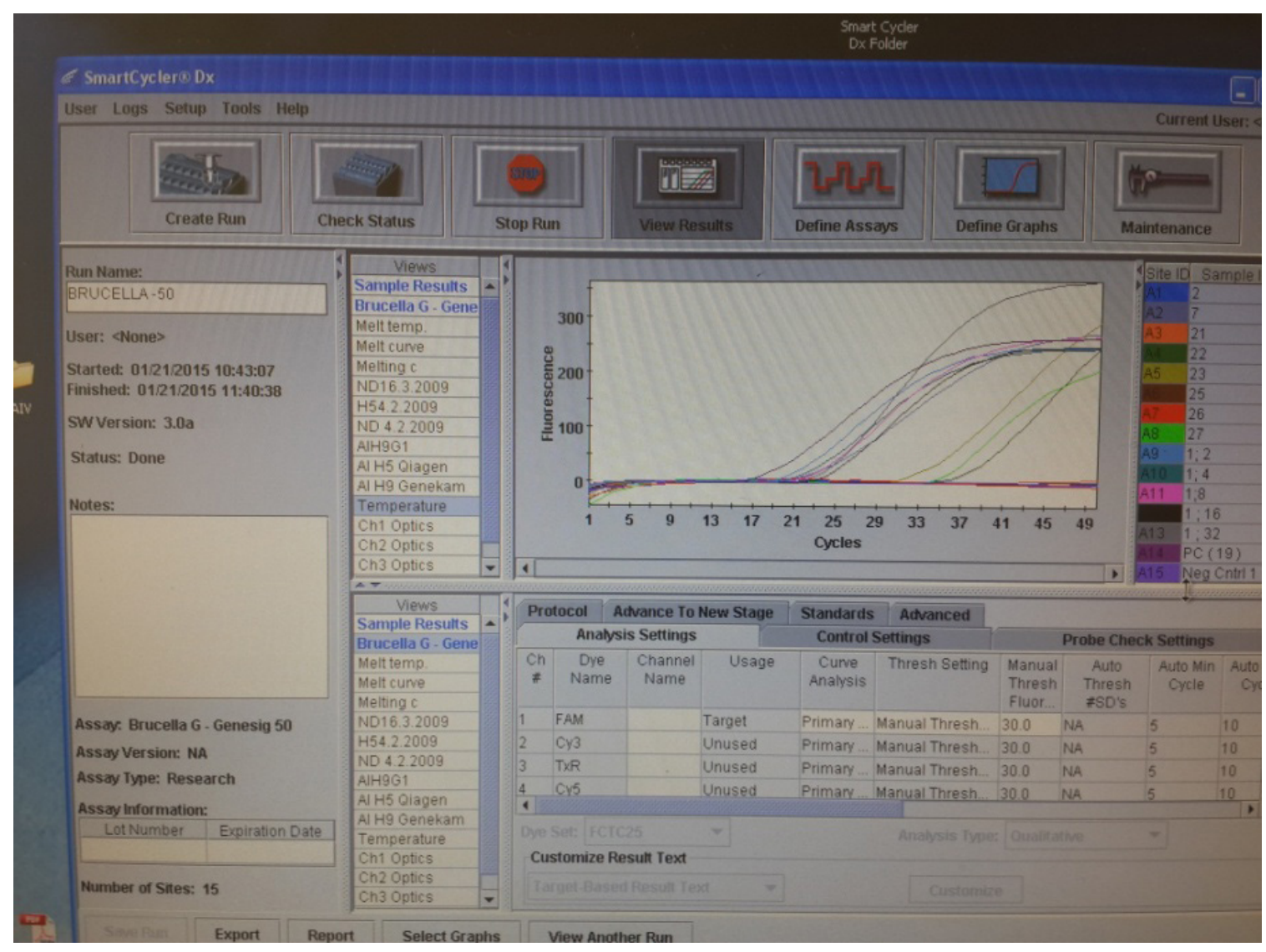

Fig. 1. Performance of RT-q PCR. No significant fluorescence was observed in negative milk samples and negative control. 


\section{CONCLUSION}

The main purpose of this study was to detect Brucella in milk samples from sero-positive animals using Brucella group RT- $q$ PCR protocol developed in-house. This technique proved to be really useful for rapid quarantine of infected animals, for the implementation of preventive measures and for the outbreaks management. Up to now no article has documented about RT- $q$ PCR investigation of Brucella genome in milk samples from Palestine. This will enable the veterinary services control and eradicate Brucellosis in Palestine.

\section{REFERENCES}

1. AGaradi A, Khairani-Bejo S, Zunita Z, Omar AR (2011). Detection of Brucella melitensis in blood samples collected from goats. Journal of Animal and Veterinary Advances 10:1437-1444.

2. Alton G, Jones L, Angus R, Verger J (1988). Techniques for the Brucellosis Laboratory. Institut National de la Recherche Agronomique Publications, Paris, France.

3. Bricker B (2002). PCR as a diagnostic tool for brucellosis. Vet Microbiol 90:435-446.

4. Bounaadja L, Albert D, Chenois B (2009). Real-time PCR for identification of Brucella spp: a comparative study of IS711, bcsp31 and per target genes. Vet Microbiol 137:156-164.

5. Doganay M, Aygen B (2003). Human brucellosis: an overview. Int J Infect Dis 7:173-182.

6. Doosti A, Ghasemi Dencodri P (2011). Application of real time PCR for identification and differentiation of Brucella abortus and Brucella melitensis in cattle. Bul J of Vet Med 14(2):109-115.

7. FAO (2010). Brucella melitensis in Eurasia and the Middle East. FAO Animal Production and Health Proceedings 10, Rome.

8. Foster T, Okinaka R, Svensson R, Shaw K, De B, Robison R, Probert W, Kenefic L, Brown W, Keim P (2008). Real-time PCR assays of single- nucleotide polymorphisms defining the major Brucella clades. J of Clin Microbiol 46:296301.

9. Garcia-Yoldi D, Marin C, Miguel M, Munoz P, Vizmanos J (2006). Multiplex PCR assay for the identification and differentiation of all Brucella species and the vaccine strains Brucella abortus S19 and RB51 and Brucella melitensis Rev 1. Clin Chem 52:779-781.

10. Gul T, Khan A (2007). Epidemiology and epizootology of brucellosis: A review. Pakistan Vet J 27:145-151.

11. Gwida M, El-Gohary H, Melzer F, Tomaso H, Rösler U, Wernery U, Wernery R, Elschner C, Khan I, Eickhoff M, Schöner D, Neubauer H (2011). Comparison of diagnostic tests for the detection of Brucella spp. in camel sera. BMC Research Notes 4:525.

12. Kaoud A, Zaki M, El-Dahshan A, Nasr S (2010). Epidemiology of brucellosis among farm animals. Nature and Science 8:190-197.
13. Mayer-Scholl A, Draeger A, Gollner C, Scholz C, Nockler K (2010). Advancement of a multiplex PCR for the differentiation of all currently described Brucella species. J Microbiol Meth 80(1):112-114.

14. Mirnejad R, Doust H, Kachuei R, Mortazavi M, Khoobdel M, Ahamadi A (2012). Simultaneous detection and differentiates of Brucella abortus and Brucella melitensis by combinatorial PCR. Asian Pacific J of Tropical Med 5:24-28.

15. López Goñi I, García Y, Marín C, De Miguel M, Muñoz P, Blasco J, Jacques I, Grayon M, Cloeckaert A, Ferreira A, Cardoso R, Sá Mi C, Walravens K, Albert D, Garin- Bastuji B (2009). Evaluation of a multiplex PCR assay (Bruce-ladder) for molecular typing of all Brucella species, including the vaccine strains. J Clin Microbiol 46(10):3484-3487.

16. Navarro E, Escribano J, Fernandez J, Solera J (2002). Comparison of three different PCR methods for detection of Brucella spp. in human blood samples. FEMS Immunol Med Microbiol 34:147-151.

17. Navarro-Martinez A, Navarro E, Castano M, Solera J (2008). Rapid Diagnosis of Human Brucellosis by Quantitative Real-Time PCR: a case report of Brucella Spondylitis. J of Clin Microbiol 46:385-387.

18. Newby T, Hadfield T, Roberto F (2003). Real-time PCR detection of Brucella abortus: A comparative study of SYBRgreen I, 5'-exonuclease, and hybridization probe assays. App and Env Microbiol 69:4753-4759.

19. Ning P, Guo M, Guo K, Xu L, Ren M, Cheng Y, Zhang Y (2013). Identification and Effect Decomposition of Risk Factors for Brucella Contamination of Raw Whole Milk in China. PLoS ONE 8(7): e68230.

20. O'Leary S, Sheahan M, Sweeney T (2006). Brucella abortus detection by PCR assay in blood, milk and lymph tissue of serologically positive cows. Res Vet Sci 81:170-176.

21. Romero C, Lopez-Goni I (1999). Improved Method for Purification of Bacterial DNA from Bovine Milk for Detection of Brucella spp. by PCR. App and Env Microbial 65(8):3735-3737.

22. Probert W, Schrader K, Khuong N, Bystrom S, Graves M (2004). Real-Time Multiplex PCR Assay for Detection of Brucella spp, B.abortus, B. melitensis. J of Clin Microbiol 42:1290-1293.

23. Refai M (2002). Incidence and control of brucellosis in the Near East region. Vet Microbiol 90:81-110.

24. Safarpoor-Denkordi F, Kahamesipour F, Momeni M (2014). Brucella abortus and Brucella melitensis in Iranian Bovine and Buffalo Semen Samples: The First Clinical Trial on Seasonal, Senile and Geographical Distribution Using Culture, Conventional and Real-time Polymerase Chain Reaction Assays. Kafkas Univ Vet Fak Derg 20(6): 821828.

25. Saleem N, Boyle M, Sriranganathan N (2010). Brucellosis: a re-emerging zoonosis. Vet Microbiol 140(3-4):392-398.

26. Sanco (Scientific Committee on Animal Health and Animal Welfare) (2001). Brucellosis in sheep and goats (Brucella melitensis). European Commission, Health and Consumer Protection Directorate- General. 
27. Scholz H, Vergnaud G (2013). Molecular characterisation of Brucella species. Rev Sci Tech Off Int Epiz 32(1):149162.

28. Sohrabi M, Mohabati Mobarez A, Behmanesh M, Khoramabadi N, Doust R (2011). Evaluation of a new set of Real-Time PCR for Brucella detection within human and animal samples. JPHS 1(2):11-15.

29. Surucuoglu S, El S, Ural S, Gazi H, Kurutepe S, Taskiran $P$, Yurtsever S (2009). Evaluation of real-time PCR method for rapid diagnosis of brucellosis with different clinical manifestations. Polish J of Microbiol 58:15-19.
30. Zvizdic S, Cengic D, Bratic M, Mehanic S, Pinjo F, Hamzic S (2006). Brucella melitensis review of the human infection case. Bosnian J of Basic Med Sci 6:15-18.

31. Yousef-Beingi G, Rad M, Hosseine M, Jafari A (2005). Effect of centrifugation of milk samples on bacteriological culture. Iranian J of Vet Res, University of Shiraz 6(1),11.

32. WHO (World Health Organization)(1999). Human and animal Brucellosis: Epidemiological Surveillance in the MZCP Countries. Report of a WHO/MZCP Workshop, Damascus, Syrian Arab Requblic, 4-5 May 1998, Athens 1999. 